\title{
Association between the habit of reading food labels and health-related factors in elderly individuals of the community
}

\section{Associação entre hábito de leitura de rótulos de alimentos e fatores relacionados à saúde em idosos da comunidade}

\author{
Ana Carolina VERÍSSIMO1 (iD) 0000-0002-8115-3265 \\ Maria Cristina de Albuquerque BARBOSA ${ }^{1}$ (D) 0000-0003-2957-342X \\ Nizia Araújo Vieira ALMEIDA ${ }^{1}$ (DD 0000-0001-8817-757X \\ Andreia Cristiane Carrenho QUEIROZ2 (D) 0000-0003-1985-2388 \\ Regina Gendzelevki KELMANN³ (ID) 0000-0003-3240-4555 \\ Clarice Lima Alvares da SILVA ${ }^{1}$ iD 0000-0002-1257-8964
}

\section{A B S T R A C T}

\section{Objective}

To investigate the association between the habit of reading food labels and health related factors in elderly individuals who are members of social groups in the city of Governador Valadares, in the state of Minas Gerais, Brazil.

${ }^{1}$ Universidade Federal de Juiz de Fora, Instituto de Ciências da Vida, Departamento de Nutrição. Campus Governador Valadares Av. Dr. Raimundo Monteiro Rezende, 330, Centro, 35010-177, Governador Valadares, MG, Brasil. Correspondence to: CLA SILVA, E-mail: <clarice.silva@ufjf.edu.br>

2 Universidade Federal de Juiz de Fora, Instituto de Ciências da Vida, Departamento de Educação Física. Governador Valadares, MG, Brasil.

3 Universidade Federal de Juiz de Fora, Instituto de Ciências da Vida, Departamento de Farmácia. Governador Valadares, MG, Brasil.

Support: Universidade Federal de Juiz de Fora through the Programa Institucional de Bolsas de Iniciação Cientifica 2014/2015 public notice; the Ministry of Education through the PROEXT 2015 public notice; and the Fundação de Amparo à Pesquisa do Estado de Minas Gerais process No.APQ00133-14)

How to cite this article

Veríssimo AC, Barbosa MCA, Almeida NAV, Queiroz ACC, Kelmann RG, Silva CLA. Association between the habit of reading food labels and health-related factors in elderly individuals of the community. Rev Nutr. 2019;32:e180207. http:// dx.doi.org/10.1590/1678-9865201932e180207 


\section{Methods}

This cross-sectional study interviewed 141 individuals, members of elderly social groups. The socioeconomic and health profile was defined based on sex, age, marital status, educational level, disease occurrence, use of medication, physical exercise and self-perception of health. The habit of reading the food labels was assessed through the question: "Do you read the food label before purchasing or consuming the product?". In case of an affirmative answer, researchers asked which items from the labels were observed by the individual. Weekly food intake was assessed through a food frequency questionnaire and classified in scores. The anthropometric evaluation was based on the calculation and classification of the Body Mass Index. A multinomial logistic regression was used to determine factors associated with the habit of reading the labels, and it was considered significant when $p<0.025$.

\section{Results}

The habit of reading labels was reported by $72.3 \%$ of the participants, whom predominantly verified the product's expiration date (90.2\%), followed by the amount of fat (18.4\%) and sodium (16.7\%) in it. This behavior was independently associated with a lower mean consumption of medicines, a lower per capita household consumption of sugar and a higher weekly frequency of per capita whole grain consumption.

\section{Conclusion}

The habit of reading the food labels is associated with a better health condition and with a healthier eating behavior among elderly individuals and it should be considered as an important nutritional strategy in this age group.

Keywords: Aged. Feeding behavior. Health status. Nutritional labeling. Nutritional status.

\section{R E S U M O}

\section{Objetivo}

Investigar a associação entre hábito de leitura de rótulos de alimentos e fatores relacionados à saúde entre idosos participantes de grupos de convivência em Governador Valadares.

\section{Métodos}

Este estudo transversal entrevistou 141 idosos participantes de grupos de terceira idade. O perfil socioeconômico e de saúde foi definido pela identificação de sexo, idade, estado civil, escolaridade, ocorrência de doenças, uso de medicamentos, exercício físico e autopercepção da própria saúde. A leitura de rótulos foi avaliada pela pergunta: "O(A) Senhor(a) verifica o rótulo de alimentos antes de sua compra ou consumo?", questionando-se os itens avaliados em caso de resposta positiva. O consumo alimentar semanal foi avaliado por meio do questionário de frequência alimentar e classificado por meio de escores. A avaliação antropométrica se baseou no cálculo e classificação do Índice de Massa Corporal. A regressão logística multinomial foi utilizada para determinar fatores associados ao hábito de leitura de rótulos, adotando-se p<0,025 para significância da associação.

\section{Resultados}

O hábito de leitura de rótulos foi relatado por 72,3\% dos entrevistados, que verificavam predominantemente prazo de validade (90,2\%), teores de gorduras (18,4\%) e sódio (16,7\%). O mesmo se associou independentemente ao menor consumo mediano de medicamentos, menor consumo familiar per capita de açúcar e maior frequência de consumo semanal de cereais integrais.

\section{Conclusão}

O hábito de leitura de rótulos alimentares esteve associado a melhores condições de saúde e comportamentos alimentares mais saudáveis entre idosos da comunidade, devendo ser considerado como importante estratégia nutricional nesta faixa etária.

Palavras-chave: Idoso. Comportamento alimentar. Nível de saúde. Rotulagem de alimentos. Estado nutricional.

\section{NTRO D U C T I O N}

The aging process of the Brazilian population has been occurring rapidly and it is associated with the process of nutritional transition, which can be translated into new challenges for the 
adequate health care of elderly individuals in the country [1]. Nutrition is an important factor for a healthy aging process, given that body changes and/or illnesses that are common at this stage of life may reflect into changes in dietary needs and/or consumption, making the elderly individual vulnerable to various nutritional problems [2,3], including low weight or excess weight, sarcopenia, nutrient deficiencies and chronic noncommunicable diseases $[4,5]$.

The elderly population in Brazil has low educational levels (70.5\% of these individuals only did elementary school) and income (75.2\% do not work and live from their retirement pensions). The occurrence of diseases is frequent in this group (62.8\% have hypertension, $35.4 \%$ have hypercholesterolemia, $21.2 \%$ have diabetes) and about one third of them have a habit of replacing proper meals with sandwiches. Approximately $77.0 \%$ of elderly individuals are overweight, with the southeastern region of the country being one of the most prevalent for this condition $[6,7]$.

Food labeling is an allied tool in the food and nutrition education of the population, favoring healthier and more adequate choices, autonomously and independently for the prevention of nutritional disorders and diseases [8]. Studies on this subject regarding the elderly population of the country are scarce, include other age groups, and are concentrated in the South and Center-West regions of Brazil. Their results indicate that reading food labels is a frequent habit for most of the interviewees, being associated with the occurrence of overweight, chronic diseases [9], and to the attempt of improving eating habits and quality of life [10], with the expiration date being the most verified item [11]. Other studies indicate that the nutritional information contained in the labels is considered difficult to read by elderly individuals due to the highly technical language, abbreviations, acronyms, and the use of small letters $[8,12]$.

In Brazil, food labeling has been regulated by specific legislation since 2003, with mandatory explicit nutrition information for all packaged foods, including energy, carbohydrates, proteins, total fats, saturated fats, trans fats, dietary fiber and sodium values [13]. Starting in 2017, the Agência Nacional de Vigilância Sanitária (ANVISA, Brazilian National Agency of Sanitary Surveillance), through its working group, diagnosed problems in food labels regarding the transmission of nutritional information to the population, generating discussions on proposals for adequacy and improvements in the nutritional table, and front labels with warnings for foods with high sugar, fat and sodium contents through colors, symbols and qualitative descriptors [14].

In view of the above, the present study investigated the association between the habit of reading food labels and the factors related to the health of elderly individuals who are members of social groups in the city of Governador Valadares, in the state of Minas Gerais (Brazil). The expansion of knowledge about this subject becomes essentially useful for comparing different labeling proposals, allowing the evaluation of the impact of future changes in improving the access and the comprehension of the information contained in food labels by the general population.

\section{METHOD S}

This is an epidemiological cross-sectional exploratory study about the habit of reading food labels and their associated factors among elderly individuals living in the city of Governador Valadares. Located in the Rio Doce Valley, in the east of the state capital, it has an average population of 263,689 inhabitants, with the percentage of elderly individuals ( $\geq 60$ years) being $11.7 \%$ of that population [15]. The study was carried out with a convenience sample of 141 individuals of both sexes, aged 60 years or older, who signed up for activities offered by three elderly social groups in 
the city during the study period (2014-2016). All 161 elderly individuals who were members of these groups were invited to participate. Of these, two (1.2\% of the sample universe) did not attend the data collection events. Eighteen individuals (11.2\% of the sample universe) who did not answer the questions related to the reading of food labels had their data excluded.

For data collection, it was used a questionnaire structured by the researchers. A properly trained team of health graduates collected the data through a face-to-face interview at the places where the social group meetings were being held. To characterize the socioeconomic and health conditions of elderly individuals, their age, sex, educational level ( $<4$ years or $\geq 4$ years), and marital status (with a partner or without a partner), and the self-reported presence of chronic diseases (prior disease diagnosis), the use of medicines (number of medications consumed during the interview period), the self-perception of their own health (poor, reasonable, good or very good) and physical activity (at least 150 minutes of physical activities per week, in the last month before the interview) [16].

Dietary habits were assessed by checking the number of meals people had per day, as well as the use of dietary sweeteners by them. In addition, the consumption of sugar, oil, and salt were evaluated by means of the per capita monthly availability of sugar, salt, and kitchen oil, and this measure was obtained by reporting the quantity in grams/milliliters of these cooking ingredients which are purchased monthly for the household and divided equally among its residents. The habit of reading labels was assessed by asking the question: "Do you check the food label before it is purchased or consumed?". The elderly individuals who responded affirmatively to this question were then asked about the information they observed (expiration date, list of ingredients, energy, carbohydrates, proteins, fats, dietary fiber, sodium values and/or other items) were questioned. A Food Frequency Questionnaire (FFQ) was used to evaluate food consumption for the 6-month period prior to the interview. In this instrument, all the food groups described in the Food Guide for the Brazilian Population [17] were included, guaranteeing the representativeness of the habit and food culture of the evaluated population. Consumption frequency options included 11 categories that ranged from "never" to "daily", ranged from 1 to 6 times per week, or 1 to 3 times per month. These were converted into a numerical score of weekly food consumption, previously defined by the researchers, being attributed a " 0 " score for items which were not consumed, increasing progressively until the "7" score for daily consumption, as described in Table 1.

Table 1. Corresponding Weekly Consumption Frequency Categories and Weekly Consumption Scores. Governador Valadares (MG), Brazil, 2014-2016.

\begin{tabular}{|c|c|c|c|c|c|c|c|c|c|c|c|}
\hline \multirow{2}{*}{ Frequency of consumption } & \multirow{2}{*}{ Never } & \multicolumn{7}{|c|}{ Weekly (Times/Week) } & \multicolumn{3}{|c|}{ Monthly (Times/week) } \\
\hline & & Daily & 1 & 2 & 3 & 4 & 5 & 6 & 1 & 2 & 3 \\
\hline Scores of weekly consumption & 0 & 7 & 1 & 2 & 3 & 4 & 5 & 6 & 0.25 & 0.5 & 0.75 \\
\hline
\end{tabular}

The anthropometric evaluation of the elderly individuals was based on measures of weight, stature, and the subsequent calculation of their Body Mass Index (BMI). The weight was measured with a WISO portable digital scale, Ultra Slim W801 ${ }^{\circledR}$ model (São José, Santa Catarina, Brazil), measuring up to 180 kilos and with a precision rate of 100 grams. Individuals were placed in the center of the equipment, wearing the least amount of clothing, barefoot, erect, with their feet together and their arms extended along the body, with their weight being taken after it was stabilized in the scale, and the form was subsequently filled with this information [18]. 
Stature was measured using the Alturexata ${ }^{\circledR}$ (São Paulo, Brazil) portable stadiometer, with a capacity of 2.13 meters and a precision rate of $1 \mathrm{~mm}$. For this, elderly individuals were placed barefoot, without wearing any kinds of hats or props, in the center of the equipment. Standing up, erect, with their arms outstretched along the body, their heads up, looking at a fixed point at eye level. The head of the individual was positioned in the "Frankfurt plane" (with the lower margin of the opening of the orbital septum and the upper margin of the external auditory meatus in the same horizontal line). The legs were in a parallel position, with the heels, calves, buttocks, scapulae and the posterior part of the head (occipital region) at a right angle to the stadiometer, when it was not possible to position all the points, the researchers positioned at least 3 of these points. The moveable head board was lowered, resting it against the head, with enough pressure to compress the hair. The individual was removed when the researchers made sure that he did not move. The stature was read, without releasing the equipment's moveable head [18].

The BMI was used to evaluate the body mass distribution in elderly individuals, representing the relationship between the individual's weight in kilos and the square of the individual's height in meters $\left(\mathrm{kg} / \mathrm{m}^{2}\right)$ [19]. Their classification was based on the cut-off point proposed by Lipschitz [20], which considers values below $22 \mathrm{~kg} / \mathrm{m}^{2}$ as underweight and values equal or greater than $27 \mathrm{~kg} / \mathrm{m}^{2}$ as overweight.

Data were tabulated and analyzed using the Stata ${ }^{\circledR}$ statistical software, version 10.0. (Stata Corp., College Station, Texas, United States) The dependent variable of this study was the reading habit of food labels, all others being considered exploratory variables. The analysis of the normal distribution of the quantitative data was performed by the skewness coefficient. Categorical data were presented in their absolute $(n)$ and relative (\%) frequency values, while the quantitative data were described in mean and standard deviation values. The multinomial logistic regression was used to determine the factors associated with the habit of reading food labels, estimating the Odds Ratio (OR) and a 95\% Confidence Interval $(95 \% \mathrm{Cl})$. In the initial logistic model, all the variables that showed an association with the dependent variable in the univariate analysis were included, at a level of significance lower than 0.20 . The variables that showed an association at a level below 0.025 were maintained in the final logistic model. This level of significance was adopted after Bonferroni's correction, to avoid the occurrence of type I errors. The Hosmer-Lermershow test was also applied to guarantee the adjustment of the final model.

The basic research for this project was approved by the Ethics Committee in Research on Human Beings of the Universidade Federal de Juiz de Fora (UFJF, Federal University of Juiz de Fora), protocol No.1.233.097, and all the requirements expressed in resolution 466/2012 [21] were respected. All the participants signed the Informed Consent Term and received their individual results of the nutritional evaluation, with guidelines on healthy habits.

\section{RES ULTS}

The habit of reading food labels was reported by $72.3 \%(n=102)$ of the elderly individuals in the study. Figure 1 shows the frequency of evaluation of different labeling items. Expiration date $(90.2 \%)$, fat (18.6\%) and sodium (16.7\%) contents were the most verified information by elderly individuals when inspecting food packagings. 


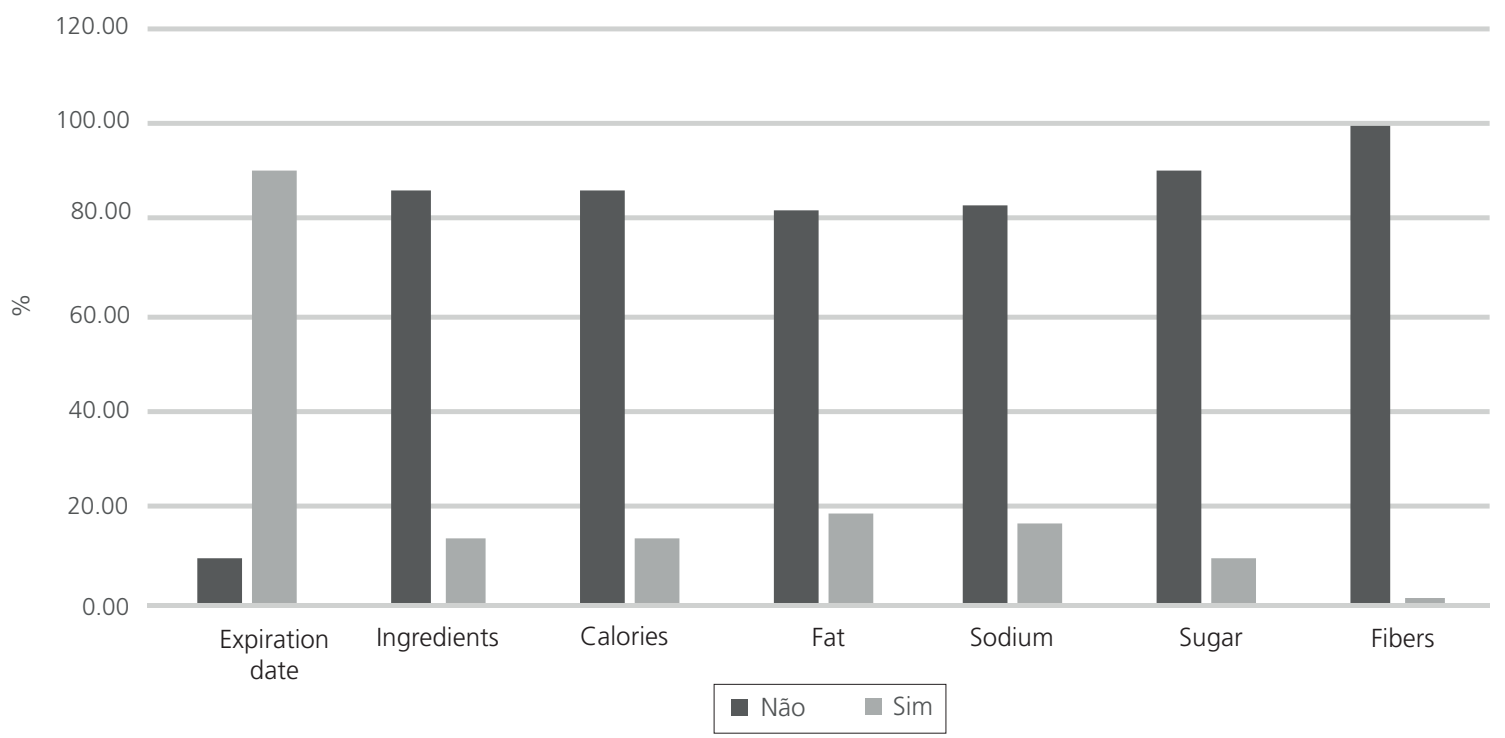

Figure 1. Items verified in food labels by active elderly individuals of the community. Governador Valadares (MG), Brazil, $2014-2016$. $(n=141)$.

Table 2 shows the socioeconomic and health characteristics of the participants, their characteristics in general and according to the habit of reading food labels. The elderly individuals in this study had a mean age of 70.2 years (Standard Deviation $[S D]=6.8$ ) and were mostly women $(88.7 \%)$, without partners $(59.6 \%)$, with less than 4 years of education $(84.4 \%)$, and physical activity practitioners (66.4\%). The mean incidence of diseases was 1.8 (SD=1.1) and was self-reported by $90.1 \%$ of the individuals, with hypertension (61.7\%) and diabetes $(17.7 \%)$ the most mentioned ones. The mean continuous use of three (SD=2.2) medications per day and the occurrence of polypharmacy (the use of four or more medications per day) was observed in $23.7 \%$ of the cases. The mean BMI was $27.9 \mathrm{~kg} / \mathrm{m}^{2}(\mathrm{SD}=4.3)$, with $57.2 \%$ of participants being diagnosed as overweight. The majority $(65.0 \%)$ classified their own health as good or very good.

Table 3 shows the eating characteristics of the individuals, their general food consumption and according to the habit of reading food labels. There was an average of 4.7 ( $S D=0.98)$ daily meals. The mean per capita consumption of sugar, oil and salt was $56.0 \mathrm{~g}(\mathrm{SD}=40.9), 27.6$ milliliters $(S D=17.9)$ and $9.6 \mathrm{~g}(S D=7.1)$, respectively. The foods with the highest frequency of average weekly consumption were dairy products, legumes, refined grains, and fruits, while oilseeds, foods with high fat contents, sweets, and soft drinks presented a lower weekly consumption.

In the univariate data analysis, the habit of reading labels was significantly associated with a lower sugar consumption and a higher frequency of consumption of whole grains $(p<0.025)$ (Tables 2 and 3).

In addition to the variables with statistical significance, the number of medicines consumed, the number of meals consumed daily, the frequency of consumption of vegetables, 
foods with high fat contents, roots, and offal $(p<0.20)$ (Tables 2 and 3). In the final model, the habit of reading food labels remained independently and significantly associated with a lower average number of medicines consumed, a lower average per capita sugar consumption, and a higher average weekly consumption of whole grains (Table 4).

Table 2. Socioeconomic and health characteristics of the elderly individuals. Governador Valadares (MG), Brazil, $2014-2016$ $(n=141)$.

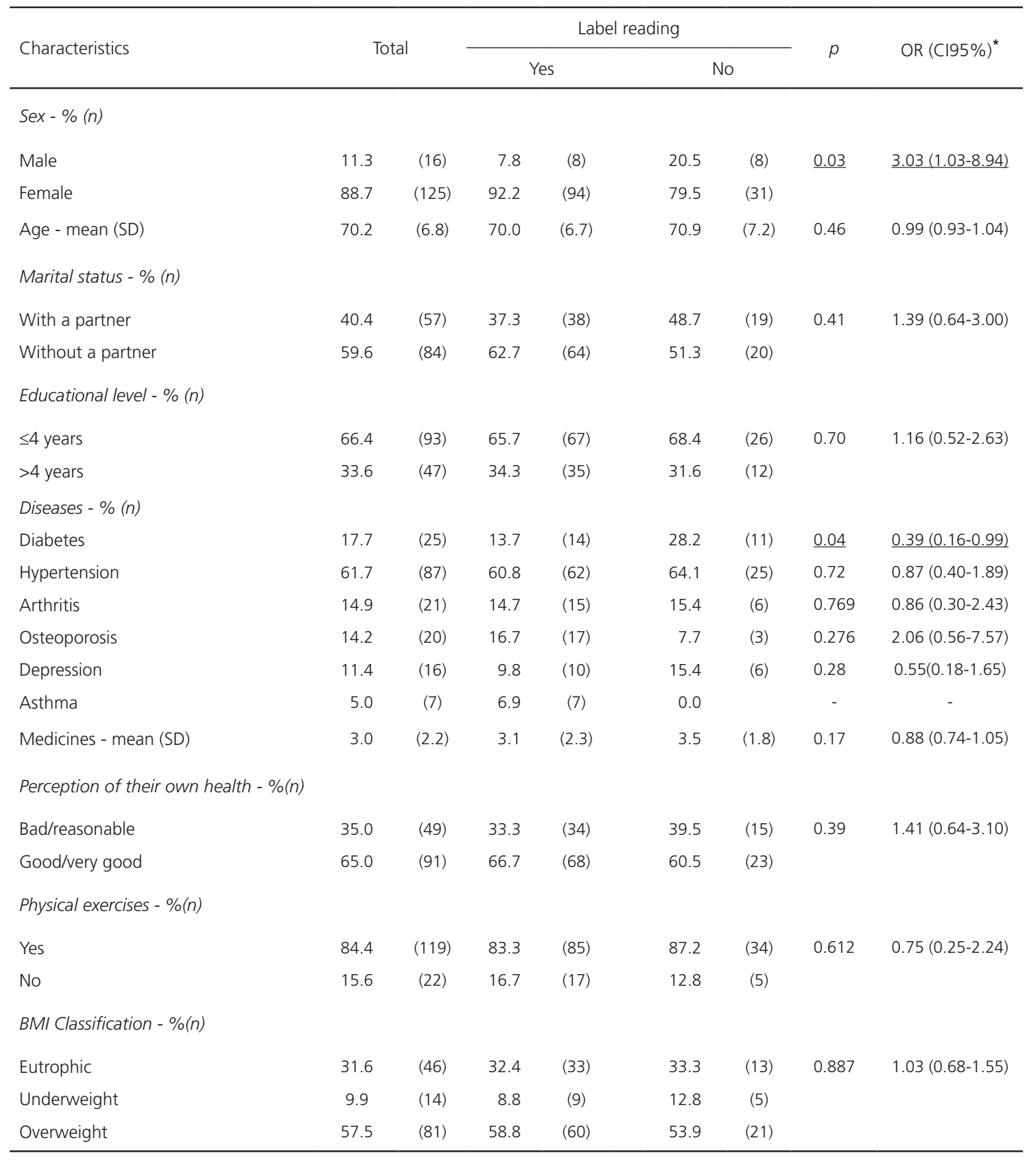

Note: *OR (C195\%): Odds Ratio (95\% Confidence Interval). Underlined values presented $p<0.20$.

BMI: Body Mass Index; SD: Standard Deviation. 
Table 3. Characteristics and eating habits of elderly individuals, members of the community. Governador Valadares (MG), Brazil, 2014-2016 (n=141).

\begin{tabular}{|c|c|c|c|c|c|c|c|c|}
\hline \multirow{2}{*}{ Characteristics } & \multirow{2}{*}{\multicolumn{2}{|c|}{ Total }} & \multicolumn{4}{|c|}{ Label reading } & \multirow{2}{*}{$p$} & \multirow{2}{*}{ OR $(C 195 \%)^{*}$} \\
\hline & & & \multicolumn{2}{|c|}{ Yes } & \multicolumn{2}{|c|}{ No } & & \\
\hline \multicolumn{9}{|l|}{ Perception of their own eating habits \% ( $n$ ) } \\
\hline Bad/reasonable & 28.4 & (40) & 30.4 & (31) & 23.1 & (9) & 0.475 & $0.73(0.31-1.74)$ \\
\hline Good/very good & 71.6 & (101) & 69.6 & (71) & 76.9 & (30) & & \\
\hline Number of meals - Mean (SD) & 4.7 & $(0.98)$ & 4.8 & $(0.98)$ & 4.4 & $(0.94)$ & $\underline{0.08}$ & $1.40(0.96-2.06)$ \\
\hline Sugar consumption ${ }^{+}$- Mean (SD) & 56.0 & $(40.9)$ & 48.0 & $(32.0)$ & 77.7 & $(54.2)$ & 0.002 & $0.98(0.97-0.99)$ \\
\hline Kitchen oil consumption ${ }^{+}$- Mean (SD) & 27.6 & $(17.9)$ & 26.5 & $(18.5)$ & 30.3 & $(15.9)$ & 0.36 & $0.99(0.96-1.01)$ \\
\hline Salt consumption ${ }^{+}-$Mean (SD) & 9.6 & $(7.1)$ & 9.7 & $(7.8)$ & 9.3 & $(5.0)$ & 0.724 & $1.01(0.94-1.09)$ \\
\hline \multicolumn{9}{|l|}{ Sweetener consumption \% ( $n$ ) } \\
\hline Yes & 36.9 & $(52)$ & 36.3 & (37) & 38.5 & (15) & 0.814 & $0.91(0.42-1.98)$ \\
\hline No & 63.1 & (89) & 63.7 & $(65)$ & 61.5 & (24) & & \\
\hline \multicolumn{9}{|l|}{ Food consumption ${ }^{1}$ - Mean (SD) } \\
\hline Fruits & 5.90 & $(2.0)$ & 5.9 & $(2.0)$ & 5.9 & $(2.0)$ & 0.94 & $1.01(0.83-1.21)$ \\
\hline Leafy vegetables & 5.60 & $(2.2)$ & 5.4 & $(2.1)$ & 5.8 & $(2.1)$ & 0.366 & $0.92(0.77-1.10)$ \\
\hline Non-leafy vegetables & 5.10 & $(2.4)$ & 4.9 & $(2.4)$ & 5.6 & $(2.1)$ & $\underline{0.07}$ & $\underline{0.85(0.72-1.02)}$ \\
\hline Whole Grains & 2.50 & $(3.1)$ & 2.9 & $(3.2)$ & 1.4 & $(2.6)$ & 0.01 & $1.19(1.03-1.37)$ \\
\hline Refined Cereals & 6.30 & $(1.7)$ & 6.3 & $(1.8)$ & 6.4 & $(1.6)$ & 0.977 & $0.99(0.79-1.24)$ \\
\hline Dairy Products & 6.90 & $(3.2)$ & 6.8 & $(3.1)$ & 7.3 & (3.5) & 0.479 & $0.96(0.85-1.1)$ \\
\hline Roots & 2.50 & $(2.2)$ & 2.7 & $(2.3)$ & 2.0 & $(2.0)$ & $\underline{0.08}$ & $\underline{1.19(0.98-1.46)}$ \\
\hline Legumes & 6.20 & $(1.8)$ & 6.3 & $(1.7)$ & 6.2 & $(2.0)$ & 0.513 & $1.07(0.87-1.31)$ \\
\hline Oilseeds & 1.70 & $(2.6)$ & 1.8 & $(2.6)$ & 1.3 & $(2.5)$ & 0.336 & $1.08(0.92-1.27)$ \\
\hline Red meat & 3.10 & $(1.9)$ & 3.1 & $(1.9)$ & 3.0 & $(2.0)$ & 0.512 & $1.07(0.87-1.31)$ \\
\hline White meat & 2.90 & $(1.8)$ & 2.9 & $(1.7)$ & 2.9 & $(2.1)$ & 0.804 & $0.97(0.79-1.20)$ \\
\hline Offal & 0.34 & $(0.6)$ & 0.4 & $(0.6)$ & 0.2 & $(0.4)$ & $\underline{0.112}$ & $\underline{2.23(0.83-6.02)}$ \\
\hline Eggs & 2.00 & $(1.6)$ & 1.9 & $(1.6)$ & 2.0 & $(1.8)$ & 0.641 & $0.95(0.75-1.18)$ \\
\hline Foods with high fat content & 1.00 & $(1.5)$ & 0.8 & $(1.3)$ & 1.4 & (1.9) & $\underline{0.113}$ & $\underline{0.82(0.65-1.05)}$ \\
\hline Candies and Sweets & 1.90 & $(2.6)$ & 2.0 & $(2.6)$ & 1.9 & $(2.8)$ & 0.931 & $1.01(0.87-1.16)$ \\
\hline Soft drinks & 1.00 & $(1.8)$ & 1.1 & $(1.9)$ & 0.9 & (1.6) & 0.554 & $1.07(0.86-1.34)$ \\
\hline
\end{tabular}

Note: * OR (C195\%): Odds Ratio (95\% Confidence Interval). Values in bold presented $p<0.025$. Underlined values presented $p<0.20 .{ }^{+}$Monthly per capita household availability. ${ }^{1}$ Mean scores of weekly consumption frequency. SD: Standard Deviation.

Table 4. Associated factors (Adjusted $\mathrm{OR}$ and $\mathrm{Cl} 95 \%$ *) to the habit of reading food labels among elderly individuals. Governador Valadares (MG), Brazil, 2014-2016, $(n=141)$.

\begin{tabular}{|c|c|c|c|}
\hline Characteristics & Adjusted OR (C195\%) $)^{*}$ & Adjusted $p^{2}$ & $p$ value - Hosmer - Lemeshow ${ }^{3}$ \\
\hline Number of medicines & $0.77(0.62-0.97)$ & 0.02 & \\
\hline Sugar consumption ${ }^{+}$ & $0.98(0.97-0.99)$ & 0.001 & 0.05 \\
\hline Weekly Consumption of Whole Grains ${ }^{1}$ & $1.31(1.08-1.59)$ & 0.007 & \\
\hline
\end{tabular}

Note: * OR (CI95\%): Odds Ratio (95\% Confidence Interval). ${ }^{+}$Monthly per capita household availability. ${ }^{1}$ Mean scores of weekly consumption frequency. ${ }^{2} \mathrm{R} 2=0,1775 .{ }^{3} p \geq 0,05$ values indicate a positive adjustment of the multivariate logistic regression model. 


\section{DISCUSSIO N}

The elderly individuals who were interviewed had low educational levels and lived alone, and a high number of chronic diseases, use of multiple medications, excessive consumption of salt and the occurrence of nutritional problems, being predominantly overweight. On the other hand, it was detected the occurrence of behaviors considered as "health protective", such as physical activity, regular consumption of fruits and vegetables, adequate consumption of sugar, oil and foods with high fat contents. A study based in the cities of the north region of the state of Rio Grande do Sul, with 424 elderly individuals, found that a population with less than 5 years of education and a high occurrence of medication use per day, while healthy attitudes were based on alcohol and/or cigarette abstinence and the regular practice of physical activities [22]. The results of a population-based study conducted in the city of Florianópolis, in the state of Santa Catarina, with 1,197 elderly individuals, showed that the majority of the participants did not work, lived with a partner or lived with other people, were overweight, consumed inadequate amounts of fruits and vegetables, and had to do more physical activities. Protective behaviors were restricted to alcohol and tobacco abstinence [23].

The participation of these elderly individuals in elderly social groups can then be related to a greater occurrence of healthy and self-care attitudes, including reading labels and healthier food choices. The vast majority of the individuals responded that they read food labels while buying and/ or consuming food. The most observed information in this context was the expiration date, a habit reported by $90.2 \%$ of them, whereas specific nutritional information was verified by a maximum of $18.9 \%$ of the individuals, mainly the fat, sodium and sugar contents. The analysis of the expiration date versus the other information is mainly due to the consumer's priority for the hygienic-sanitary conditions of the food, as well as the fact that this information is considered to be easier to understand on the label and to promote choices that reduce food waste [8]. According to Machado et al [24], when results show the expiration date as the most verified item among consumers suggests, essentially, the concern with food safety issues by the population.

Lindemann et al. [11] carried out a cross-sectional study in the health care services of the city of Pelotas, in the state of Rio Grande do Sul, Brazil, with 1,264 adult and elderly individuals of both sexes and observed that $70.9 \%$ reported having the habit of reading food labels, with the expiration date being the most verified item (73.8\%), followed by nutritional value (18.0\%) and sodium contents (11.8\%). Likewise, among younger consumers (19 to 29 years-old) who were clients of a grocery store specialized in fruits and vegetables in the city of Caxias do Sul, in the state of Rio Grande do Sul, the habit of reading labels was mentioned by $69.6 \%$ of the participants, with a preferential focus on the expiration date of the product. Of the total nutritional information available, $27.8 \%$ read only the food caloric value [25].

Data from the ANVISA, showed that, among the people who called the Hotline service of the Ministry of Health in mid-2005, 70\% of individuals (adult and elderly individuals) read the food label. A survey carried out with adult women by the Institute of Consumer Protection in 2013 found that $77 \%$ of these read the food label, being the expiration date and the nutritional composition (mainly the energy value) the most verified items [26].

A study of 1,832 people among adolescents, adults, and elderly individuals in supermarkets in the city of New Delhi, India, reported that adolescents consume more processed and high-fat content foods, while elderly individuals prefer perishable foods with high nutritional and low fat contents. The reading of food labels among the elderly individuals was based on the nutritional concerns and the health benefits that can be brought by food [27]. In the city of Umuarama, in the state of 
Paraná, Brazil, two hundred people were interviewed in supermarkets in different regions of the city and it was verified that $68.5 \%$ of the participants read the food label and $70.0 \%$ of them needed some sort of dietary intervention due to the occurrence of obesity (66.7\%), diabetes (6.3\%) and/or hypertension (5.1\%) [9].

Although the occurrence of self-reported diseases was not associated with the habit of reading food labels in the present study, it was found that elderly individuals who had this habit consumed $23 \%$ less medicines, which may point to a possible relationship between the search for nutritional information and healthier food choices for disease prevention and control. In fact, in the present study, it was found that elderly individuals who are used to reading food labels had $12 \%$ lower sugar consumption, while they consumed $31 \%$ more whole grains, compared to those who did not have this habit.

In a study carried out with 250 adult and elderly consumers of supermarkets in the city of Brasilia, the capital of Brazil, it was observed that the most mentioned reasons for reading food labels were the attempt to improve dietary habits and quality of life, as well as the prevention and/or control of chronic noncommunicable diseases, including obesity and poor dietary habits [10].

The nutritional information contained on the label is extremely importance for healthier food choices. Miller \& Cassady [28] point out that transmitting technical information to the lay population in an easily accessible format would make them more capable of using these information for a more conscious decision-making process. The evaluation of this theory has generated controversial results in the literature [29-31], either because of the variable effect of labeling on healthier food choices or the absence of this relationship. Thus, although it is known that the tools to help consumers make the best decisions are important, their mechanisms of action are still unclear. It is suggested that nutritional information can affect food choices mainly by identifying the caloric content or understanding the role of certain nutrients in the occurrence of diseases or in the promotion of health [30], such as sodium and arterial hypertension, sugar and diabetes, among others.

As demonstrated, the low interest and/or low level of knowledge about the information contained in food labels highlights the need for nutritional education so that this tool can be more effective in the fight against obesity and chronic non communicable diseases [32]. In the present study, low educational levels seem to have not influenced this habit. However, a study carried out with 130 individuals in three supermarkets located in the cities of Viçosa, Ponte Nova and Rio Pomba, in the state of Minas Gerais, Brazil, showed that when asked about the most specific nutritional information, people with lower educational levels presented difficulties for data interpretation [33].

In the present study, the elderly individuals were not questioned about their difficulties in reading food labels, if they had any issues understanding them, any issues caused by letter size, or any other reason, which may justify a non-association with the individual's educational level. Other limitations of this study include the fact that it is a cross-sectional study, which does not allow the establishment of causal relationships for the associations found here. The adoption of a non-validated FFQ and without a previous psychometric analysis could affect the reliability of this measure. However, it is emphasized that its construction involved food groups rather than isolated foods, thus reducing the risk of low representativeness of the population's diet, besides the fact that its applicability has already been tested in the clinical practice for elderly individuals in the city. Still, the convenience sample is restricted to elderly individuals living and active in the community, who are independent and with a greater participation in society, conditions that influence their behavior and, therefore, make it difficult to extrapolate the results to the elderly population in general, making larger population studies necessary. 
Despite this, it is believed that the results found here may be useful in the clinical practices for elderly care, guiding the individual and making him capable of reading and interpreting the nutritional information contained in food packaging with a focus on choosing the most suitable foods. As previously mentioned, this research can be used as a reference in the preparation of new studies within the country, contributing to the discussion and construction of new regulatory guidelines of food labeling in Brazil.

\section{CONCLUSION}

The habit of reading food labels is associated with better health conditions and healthier eating behaviors among active and independent elderly individuals of the community who participate in social groups, and this habit should be considered as an important nutritional strategy in this age group.

\section{CONTRIBUTORS}

AC VERISSIMO performed the collection and tabulation of data and wrote the manuscript. NAV ALMEIDA and MCA BARBOSA performed the data collection and revised the manuscript. ACC QUEIROZ and RG KELMANN monitored the project and revised the manuscript. CLA SILVA coordinated the project and wrote the manuscript.

\section{REFERE N CES}

1. Souza EB. Transição nutricional no Brasil: análise dos principais fatores. Cad UniFOA. 2010 [citado 13 jan 2017];5(13):49-53. Disponível em: http://revistas.unifoa.edu.br/index.php/cadernos/article/view/1025

2. Kac G, Velasquez-Mendélez G. A transição nutricional e a epidemiologia da obesidade na América Latina. Cad Saúde Pública, 2013;19(1):4-5. http://dx.doi.org/10.1590/S0102-311X2003000700001

3. Mijnarends DM, Luiking YC, Halfens RJG, Evers SMAA, Lenaerts ELA, Verlaan S, et al. Muscle, health and costs. J Nutr Health Aging. 2018;22(7):766-73. http://dx.doi.org/10.1007/s12603-018-1058-9

4. Kikutani T, Yoshida M, Enoki H, Yamashita Y, Akifusa S, Shimazaki Y, et al. Relationship between nutrition status and dental occlusion in community-dwelling frail elderly people. Geriatr Gerontol Int. 2013;3(1):50-4. http://dx.doi.org/10.1111/j.1447-0594.2012.00855.x

5. Ministério da Saúde (Brasil). Orientação para Coleta e Análise de dados antropométricos em serviços de saúde. Brasília: MS; 2011 [citado 2 out 2017]. Disponível em: http://dab.saude.gov.br/portaldab/biblioteca. php?conteudo=publicacoes/orientacoes_coleta_analise_dados_antropometricos

6. Ferreira CCD, Monteiro GTR, Simões TC. Estado nutricional e fatores associados em idosos: evidências com base em inquérito telefônico. Rev Bras Promo Saúde. 2018;31(1):1-10.

7. Pereira IFS, Spyrides MHC, Andrade LMB. Estado nutricional de idosos no Brasil: uma abordagem multinível. Cad Saúde Pública. 2016;32(5):e00178814. http://dx.doi.org/10.1590/0102-311X00178814

8. Nascimento C, Raupp SMM, Townsend RT, Balsan GA, Minossi V. Conhecimento de consumidores idosos sobre rotulagem de alimentos. Rev Epidemiol Control Infect. 2013 [citado 15 out 2017];3(4):144-7. Disponível em: http://www.ppgcardiologia.com.br/wp-content/uploads/2014/05/Conhecimento-de-consumidores-idosossobre-rotulagem-de-alimentos.pdf

9. Cassemiro IA, Colauto NB, Linde GA. Rotulagem nutricional: quem lê e por quê? Arq Ciênc Saúde Unipar. 2006;10(1):9-16. http://dx.doi.org/10.25110/arqsaude.v10i1.2006.136

10. Monteiro RA, Coutinho JG, Recine E. Consulta aos rótulos de alimentos e bebidas por frequentadores de supermercados em Brasília, Brasil. Rev Panam Salud Publica. 2005;18(3):172-7.

11. Lindemann IL, Silva MT, César JG, Mendoza-Sassi RA. Leitura de rótulos alimentares entre usuários da atenção básica e fatores associados. Cad Saúde Coletiva. 2016;24(4):478-86. http://dx.doi.org/10.1590/1414-462X 201600040234 
12. Oh C, Kim HS, No JK. Can nutrition label recognition or usage affect nutrition intake according to age? Nutrition. 2015;32(1):56-60. http://dx.doi.org/10.1016/j.nut.2015.07.004

13. Ministério da Saúde (Brasil). Agência Nacional de Vigilância Sanitária. Resolução - RDC n³60, de 23 de dezembro de 2003. Regulamento Técnico sobre Rotulagem Nutricional de Alimentos Embalados. Diário Oficial da União; 2003 [citado 15 jul 2017]. Disponível em: http://portal.anvisa.gov.br/documents/33880/2568070/ res0360_23_12_2003.pdf/5d4fc713-9c66-4512-b3c1-afee57e7d9bc

14. Agência Nacional de Vigilância Sanitária (Brasil). ANVISA quer mudanças na rotulagem nutricional de alimentos. Brasília: ANVISA; 2018 [citado 25 set 2018]. Disponível em: http://portal.anvisa.gov.br/rss//asset_ publisher/Zk4q6UQCj9Pn/ content/id/4442085

15. Instituto Brasileiro de Geografia e Estatística. Censo Demográfico 2010. Rio de Janeiro: IBGE; 2010 [citado 2 maio 2017]. Disponível em: https://cidades.ibge.gov.br

16. World Health Organization. Global recommendations on physical activity for health. Geneva: WHO; 2011 [cited 2017 Apr 15]. Available from: http://www.who.int/dietphysicalactivity/physical-activity-recommendations18-64years.pdf

17. Ministério da Saúde (Brasil). Guia Alimentar para População Brasileira. 2a ed. Brasília: MS; 2014 [citado 15 jan 2017]. Disponível em: http://www.saude.gov.br/nutricao.151p

18. Organización Mundial de la Salud. El estado físico: uso e interpretación de la antropometría. Genebra: OMS; 1995 [acceso 15 jan 2017]. Disponible en: http://www.who.int/

19. World Health Organization. Obesity: Preventing and managing the global epidemic: Report on a WHO consultation on obesity. Geneva: WHO; 1998 [cited 2017 Jan 15]. Available from: http://www.who.int/

20. Lipschitz DA. Screening for nutritional status in the elderly. Prim Care. 1994;21(1):55-67.

21. Ministério da Saúde (Brasil). Conselho Nacional de Saúde. Resolução n466 de 2012. Brasilia: MS; 2012 [citado 1 fev 2017]. Disponível em: http://bvsms.saude.gov.br/bvs/saudelegis/cns/2013/res0466_12_12_2012.html

22. Luz EP, Dallepiane LB, Kirchiner RM, Silva LAA, Silva FP, Gopinger E, et al. Perfil sociodemográfico e de hábitos de vida da população idosa de um município da região norte do Rio Grande do Sul, Brasil. Rev Bras Geriatr Gerontol. 2014;17(2):303-14. http://dx.doi.org/10.1590/\$1809-98232014000200008

23. Confortim SC, Schneider JC, Antes DL, Cembranes F, Ono LM, Marques LP, et al. Condições de vida e saúde de idosos: resultados do estudo de coorte EpiFloripa Idoso. Epidemiol Serv Saúde. 2017;26(2):305-17.

24. Machado SS, Santos FO, Albinati FL, Santos LPR. The consumers behavior regarding the label reading of food products, Brazil. Alim Nutr. 2006;17(1):97-103.

25. Marzarotto B, Alves MK. Leitura de rótulos de alimentos por frequentadores de um estabelecimento comercial. Ciênc Saúde. 2017 [citado 1 jul 2017];10(2):102-8. Disponível em: http://revistaseletronicas.pucrs. br/ojs/index.php/faenfi/article/view/24220

26. Agência Nacional de Vigilância Sanitária (Brasil). Leitura de rótulo de alimentos. Brasília: ANVISA; 2017 [citado 1 dez 2017]. Disponível em: http://portal.anvisa.gov.br

27. Vemula SR, Gavaravarapu SM, Mendu VV, Mathur P, Avula L. Use of food label information by urban consumers in India: A study among supermarket shoppers. Public Health Nutr. 2014;17(9):2104-14. http:// dx.doi.org/10.1017/S1368980013002231

28. Miller LMS, Cassady DL. The effects of nutrition knowledge of food label use: A review of the literature. Appetite. 2015;92(1):207-16.

29. VanEpps VM, Roberto CA, Park S, Economos CD, Bleich SN. Restaurant menu labeling Policy: Review of evidence and controversies. Curr Obes Rep. 2016;5(1):72-80.

30. Cantor J, Torres A, Abrams C, Elbel B. Five years later: Awareness of New York City's calories labels declined, with no changes in calories purchased. Health Affairs. 2015;34:1893-1900.

31. Wisdom J, Downs JS, Loewenstein G. Promoting healthy choices: Information versus convenience. Am Econ J Appl Econ. 2010;2(2):164-78.

32. Souza SMFC, Lima KC, Miranda HF, Cavalcanti FID. Utilização da informação nutricional de rótulos por consumidores de Natal, Brasil. Rev Panam Salud Publica. 2011;29(5):337-43.

33. Pinheiro FA, Cardoso WS, Chaves KF, Oliveira ASB, Rios AS. Perfil de consumidores em relação à qualidade de alimentos e hábitos de compras. Cient Ciênc Biol Saúde. 2011;13(2):95-102. 